UNDERGRADUATE RESEARCH IN NATURAL AND CLINICAL SCIENCE AND TECHNOLOGY (URNCST) JOURNAL Read more URNCST Journal articles and submit your own today at: https://www.urncst.com

\title{
The Role of Immune Cell Types in Ischemic Heart Disease Progression: A Systematic Review
}

Jenny J. Liu, BSc Student [1]*, Vaneeza A. Moosa, BSc Student [1], Isabelle J. Tan, BSc Student [1]

[1] Faculty of Arts \& Science, University of Toronto, Toronto, ON M5S 3G3

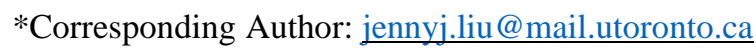

\begin{abstract}
Introduction: Globally, Myocardial Ischemia or Ischemic Heart Disease (IHD) inflicts 126 million individuals, totaling an estimated nine million deaths annually. IHD injury and healing are characterized by recruitment of several immune cell types to the cardiac tissue. In addition, atherosclerosis, a common causative factor of IHD, is initiated by mediators of innate and adaptive immunity, thus providing the rationale for studying the role of immune cell types in myocardial ischemia. Clarifying the functions and interactions among these cell types will inform drug targeting studies and ultimately facilitate development of IHD treatment and prevention approaches.

Methods: This systematic review highlights and summarizes pertinent studies evidencing the function and interaction of macrophages, monocytes, lymphocytes, platelets, and endothelial cells in IHD pathology. Electronic databases searched consist of Ovid, PubMed, Google Scholar, Web of Science, and ScienceDirect. Keywords include: "immune cells", "innate immunity", "inflammation", "cardiac macrophages", "adaptive immunity", "lymphocytes", "B cells", "T cells", "T-regulatory cells", "myocardial infarction", "reperfusion", and additional related keywords.

Results: Macrophages, monocytes, lymphocytes, platelets, and endothelial cells interact under innate and adaptive immune responses to initiate and sustain inflammation in cardiac tissue. Sustained inflammation signals for the recruitment of associated molecules to the site of ischemic heart damage which instigate injury and healing processes.

Discussion: Building a comprehensive picture of interacting cell types enables the identification of druggable targets and potential treatment and prevention options. Here, we propose several steps of IHD pathology during which further studies with agonist and inhibitor molecules may yield fruitful treatment directions. Lastly, we discuss study limitations and future research avenues.

Conclusions: Overall, explicating the immune cell type function and interactions will build a connective understanding of IHD pathology. In turn, elucidating the molecular and cell-specific mechanisms of the inflammatory immune response in cardiomyopathies will aid in the modelling of IHD disease progression as well as facilitate the identification of potential biomarkers and druggable targets to alleviate heart failure disease burden.
\end{abstract}

Keywords: myocardial ischemia; immune cells; innate immunity; inflammation; adaptive immunity; lymphocytes; myocardial infarction; reperfusion

\section{Introduction}

Globally, Myocardial Ischemia or Ischemic Heart Disease (IHD) inflicts 126 million individuals, totaling an estimated nine million deaths annually [1]. Typically referred to as coronary artery disease (CAD), IHD often clinically manifests as ischemic cardiomyopathy $(\mathrm{CM})$ and myocardial infarction (MI), or damaged cardiac muscle cells and heart attack, respectively [1,2]. Ischemia is the deficiency of oxygen; it functions in promoting tissue necrosis, the swelling and rupturing of cells that lead to cell death [3]. The common causative mechanism of IHD is the accumulation of emboli-commonly atherosclerotic plaques - in the coronary arteries [3], which restricts blood vessel diameters [4]. Resultantly, the blood oxygenation and blood supply to target organs are significantly reduced, affecting downstream biological processes and metabolic balance [3-5]. Clinical symptoms of IHD include shortness of breath; constrictions of the chest, neck, and jaw area; and cold sensations, which are further exacerbated by physical and emotional stress [2,6]. Risk factors include underlying cardiometabolic conditions such as hypertension, obesity, smoking, and a sedentary lifestyle [7]. As of yet, there are no effective treatments for IHD [8]. Considering the multifactorial nature of IHD, there are several frameworks under which IHD pathogenesis and injury may be analyzed. Of focus for this review, we will study IHD pathology through an immunological perspective. The objective of this paper is to analyze the distinct yet connected roles that various immune cells play in IHD to pave a way for the development of potential treatments. IHD is associated with 
UNDERGRADUATE RESEARCH IN NATURAL AND CLINICAL SCIENCE AND TECHNOLOGY (URNCST) JOURNAL Read more URNCST Journal articles and submit your own today at: https://www.urnest.com

an innate and adaptive immune response with particular emphasis on the inflammation, which is initiated as a mechanism for the injury and healing processes $[4,9,10]$. As key players of inflammation, several immune cell types are recruited to associated cardiac tissue; these cell types include monocytes, macrophages, T cells, B cells, platelets and endothelial cells [10,11]. Macrophages are the major phagocyte population resident in most normal tissues at homeostasis [12]. They can arise either from progenitor cells that enter the tissues during embryonic development or from circulating monocytes [12]. There are four main functions that macrophages play in immunity: they engulf and kill invading microorganisms, dispose of pathogens and infected cells targeted by adaptive immune responses, help induce inflammation, and act as scavenger cells to clear debris [12]. Monocytes circulate in the blood; during infection, they are rapidly recruited to tissue injury sites where they differentiate into macrophages [12]. B and $\mathrm{T}$ lymphocytes are responsible for initiating adaptive immune responses when they encounter cognate antigens specific to their receptors[12]. Once activated, B cells differentiate into effector plasma cells which secrete antibodies, thus playing a role in humoral immunity [12]. Similarly, activated T cells differentiate into effector CD4+ helper $\mathrm{T}$ cells and CD8+ cytotoxic $\mathrm{T}$ cells [12]. CD4+ $\mathrm{T}$ cells secrete cytokines which are vital for the function of CD8 T cells as well as the production of antibodies by plasma cells [12]. CD8+ cells directly kill threats, thus playing a role in cellular immunity [12]. Platelets play a role in the maintenance of hemostasis - the process that leads to a cessation of bleeding in the event of a blood vessel rupture [13]. Endothelial cells participate in both innate and adaptive immune responses [14]. They are one of the first cell types to detect foreign pathogens [14]. Upon the detection of microbial products in the bloodstream, endothelial cells cause the production of pro-inflammatory cytokines and chemokines, recruiting other immune cell types to the site of infection and amplifying the immune response [14]. We chose to study the role of immune cell types in ischemic heart disease due to pre-established links between atherosclerosis and cytokines. Atherosclerosis, a chronic inflammatory disorder, is initiated by endothelium activation and the recruitment of immune cells by chemokines [15]. In addition, cytokines are deeply involved in the pathogenesis of atherosclerosis [15]. As chemokines and cytokines are intertwined with both innate and adaptive immunity, and atherosclerosis is a common causative factor of IHD, we have chosen to focus on the role of immune cells in IHD. Examining the details of these mechanisms will hopefully provide different avenues to explore and focus on the role inflammation plays in IHD.

\section{Methods}

To examine the functions and interactions of immune cell types in IHD disease progression, a systematic literature review surrounding myocardial ischemia as well as the involved immune cells and processes was conducted. A keyword search was performed using electronic databases-Ovid, PubMed, Google Scholar, Web of Science, and ScienceDirect-followed by a reference list search of the bibliographies of the found studies. Inclusion criteria included the primary keyword, "myocardial ischemia," and the following secondary keywords: "immune cells", "innate immunity", "inflammation", "cardiac macrophages", "adaptive immunity", "lymphocytes", "B cells", "T cells", "T-regulatory cells", "myocardial infarction", "reperfusion", and additional related keywords. Exclusion criteria included articles that were not peer-reviewed and/or preceded the last decade (prior to 2010). Dissertations, editorials, and commentaries were excluded. A total of 147 articles were screened from the aforementioned five databases. Screening included application of inclusion and exclusion criteria as well as filtering based on title and abstract relevance. Accordingly, a total of 43 articles were retrieved for full-text review. The 43 analyzed articles consist of 23 primary research articles, 11 literature review articles, 7 meta-analyses, 1 academic textbook, and 1 web article.

\section{Results}

Current literature establishes a significant role for the inflammatory response in IHD [10,11,16-18]. Yet, there is an absence of drugs specifically targeting this inflammatory pathway, conceivably due to unsatisfactory results in early clinical trials targeting pro-inflammatory cytokines [19]. In this review, we discuss data indicating the role of macrophages, monocytes, lymphocytes, platelets, and endothelial cells in the inflammatory process to explicate a basis upon which future therapeutic options may see renewed interest.

\section{Monocytes and Macrophages}

\section{Function in Steady State of the Heart}

Presently, evidence points towards the occupancy of a significant leukocyte population in a steady-state heart [2022]. Of all the mononuclear leukocytes-lymphocytes, monocytes, macrophages, and dendritic cells-the steadystate heart is home to a dense network of macrophages [2022], henceforth known as cardiac macrophages. An examination of human myocardial samples documented the presence of cardiac macrophages [21]. Preliminary evidence using flow cytometry-based immunophenotyping indicate the presence of macrophages in myocytes, suggesting that in a steady-state heart, cardiac macrophages are in direct contact with endothelial cells and myocytes [20]. While the function of steady state macrophages has yet to be fully elucidated, research using flow cytometry methods and in vivo fate mapping of cardiomyocytes speculate that they play a role in the ingestion of pathogens, bone matrix turnover, and angiogenesis regulation $[21,22]$. 
UNDERGRADUATE RESEARCH IN NATURAL AND CLINICAL SCIENCE AND TECHNOLOGY (URNCST) JOURNAL Read more URNCST Journal articles and submit your own today at: https://www.urncst.com

\section{Function in Initiating and Sustaining of Inflammation}

Two functions of macrophages - the ability to ingest lipoproteins, giving rise to foam cells in atherosclerotic plaque [23-25], and their vigorous response to myocardial ischemia-make them particularly interesting in the study of cardiovascular health [26]. Apart from the steady state, macrophages are involved in the inflammatory events leading up to first organ ischemia. In the event of atherosclerotic plaque build-up, the interaction of chemokines with specific chemokine receptors-for instance CX3CR1, CCR5, and CCR2-and adhesion molecules on endothelial cells help to recruit monocytes. In tissues, these monocytes differentiate into macrophages, which then undergo localized proliferation to generate more macrophages [16]. Monocytes and macrophages first accumulate in the border zone of the infarction [27]. As determined by myocardium post-mortem tissues extracted at varying points after death and analyzed via immunohistochemistry and immunofluorescence, over time, macrophages will migrate into the core of the infarction [26]. As for monocytes, only in the event of reperfusion will they be distributed to the core of the infarction [27]. Reperfusion is the return of oxygenated blood into the ischemic area and is a technique used to prevent ischemia-induced fatalities [4]. However, the sudden return of additional oxygenated blood into the blood vessels may cause further tissue damage, worsening the initial injury [4]. This can often lead to MI or IHD, and possible complications for the patient [4].

Monocytes and macrophages sustain inflammation, resulting in a destabilization of both the endothelial layer and the extracellular matrix, and a weakening of vascular health [16]. In addition, macrophage cytokine Migration Inhibitory Factor (MIF) plays a crucial role in local inflammation subsequent to ischemic injury. It has been hypothesized that MIF has a role in the control of responses to various stimuli involved in the inflammatory pathway. For instance, MIF regulates the release of pro-inflammatory cytokines and is linked to numerous inflammatory disorders [28].

\section{Function in the Healing Process}

Soon after onset, IHD causes accelerated death of tissue-resident macrophages [21]. Dying macrophages function in plaque necrosis, which in turn contributes to organ ischemia [16]. On the fourth day after IHD, examination of the inflammatory and reparative phases of IHD illustrate that inflammation subsides, and infarcted macrophages switch to non-inflammatory phenotypes to promote healing [16]. At this stage, as evidenced by the larger infarct sizes of IR mice models as compared to the control mice, non-inflammatory monocytes will also be recruited to the infarcted zone [29]. The newly recruited cells play a role in infarct healing [30,31], such as the promotion of wound healing through phagocytosis and proteolysis [16].

Liu et al. | URNCST Journal (2021): Volume 5, Issue 10 DOI Link: https://doi.org/10.26685/urncst.311
Platelets and Endothelial Cells:

\section{Indicators of Inflammation}

Other crucial cell types that function in innate immunity during IHD pathogenesis and injury include platelets and activated endothelial cells. Recent studies conducted in MI patients have shown increases in mean platelet volume (MPV), platelet large cell ratio (P-LCR) and platelet distribution width (PDW) - which are all indicators of inflammation in vascular diseases, thus evidencing the increase of platelet populations in MI [32]. Platelet activation has also been shown to be a marker for acute coronary MI in humans, as demonstrated by elevated platelet function in patients [33].

\section{Interaction of Activated Platelets and Endothelial Cells}

Increases in active platelet populations tend to cause dysfunction within blood circulation. Excessive platelet activation often results in secondary ischemia in the myocardium, leading to further damage [34,35]. Past drug trials show that antiplatelet drugs provide significant therapeutic benefits to patients with coronary diseases, specifically MI [33]. Notably, platelets in MI patients aggregate at the site of ruptured atherosclerotic plaques. Activated platelets release microRNA (miRNA) - a noncoding RNA that regulates gene expression-which are taken up by endothelial cells, another key player in inflammation. In turn, this increases endothelial cell gene expression, including the expression of endothelial cell intracellular adhesion molecule-1 (ICAM-1) [36]. Past studies have shown that miRNA transfer between endothelial cells limits the effects of atherosclerosis and thus those of MI [36]. Increased expression of vascular endothelial growth factor (VEGF) in endothelial cells also play a vital role in the repair of ruptured vessels, as demonstrated by rat models. As such, similar to ICAM-1, VEGF has potential as a therapeutic target for ischemia treatment [37].

\section{The Role of Endothelial Cells in IHD Pathogenesis}

Studies suggest that endothelial cells are sensitive to IHD injury and may be critical mediators of IHD pathogenesis [38]. Endothelial cells line the inner layer of blood vessels; and under physiological conditions, they regulate the inflammatory response through inhibitory processes. Endothelial cells also function in cardiomyocyte generation and homeostasis as discovered through cell lineage tracing studies [39]. Accordingly, endothelial cells are essential for the activation of neutrophils, platelets, and plasma proteins, which help regulate the injury and inflammation processes. After an ischemic event, the surface proteins on endothelial cells are upregulated, enabling their binding and activation of neutrophils, platelets, and plasma proteins. These surface proteins include selectins and immunoglobulin cell adhesion molecules (CAM). Particularly, P-selectins and ICAM-1 enable the binding of macrophages and monocytes. 
UNDERGRADUATE RESEARCH IN NATURAL AND CLINICAL SCIENCE AND TECHNOLOGY (URNCST) JOURNAL Read more URNCST Journal articles and submit your own today at: https://www.urncst.com

Similarly, E-selectins, glycoproteins, and fibronectin receptors enable the binding of platelets. Upon platelet activation, a positive feedback mechanism is initiated whereby endothelial cell surface receptors-including selectins and ICAM - are upregulated. After binding to endothelial surface proteins, the activated molecular players then function in downstream inflammation and injury events, thus exacerbating IHD severity [40].

\section{CD4+ T Cells and B Cells:}

\section{$T$ Cells and IFN- $\gamma$ Signaling}

In addition to the role of innate immune cells, research has recently underscored the integral role of lymphocytes during IHD pathogenesis and subsequent healing [41]. Early involvement of T-helper cells and cytotoxic T cellswhich are characterized by expression of CD4 and CD8 antigens, respectively-was first evidenced using RAG1 knockout (KO) mice [42]. Through $\mathrm{T}$ cell-dependent cytokine accumulation, CD4+ $\mathrm{T}$ cells were found to mediate IHD pathology via the induction of inflammation $[43,44]$. CD4+-depleted RAG1 KO mice treated with CD4+ $\mathrm{T}$ cells derived from interferon gamma (IFN-y) $\mathrm{KO}$ mice exhibited no increase in the infarct size, as opposed to the control mice, thus evidencing the involvement of the IFN-y expression pathway in injury. Moreover, CD4+-dependent injury may be mitigated by adenosine (A2A) receptor signaling, as demonstrated by decreased infarct sizes in A2AR agonist-treated RAG1 KO mice. However, lymphocyte-deficient RAG1 KO mice reconstituted with $\mathrm{CD} 8+\mathrm{T}$ cells continued to experience cardioprotection, differing from RAG1 $\mathrm{KO}$ mice reconstituted with CD4+ T cells, which lost cardioprotection [42]. In sum, mice studies have revealed a role for $\mathrm{CD} 4+\mathrm{T}$ cells in IHD pathology. Beyond the extensive mice studies revealing CD4+-T cell dependency in IHD pathology, clinical trials have also paralleled a role for CD4+ T cells in human IHD pathology $[43,44]$.

\section{$B$ Cells and CCL7 Signaling}

It is important to note, however, that CD4+-dependent signaling does not act alone and cooperates with other lymphocytes in IHD injury, notably B cells $[43,44]$. Mice studies have shown infiltration of B cells at the infarct zone. Production of chemokine (C-C motif) Ligand 7 (CCL7) by $\mathrm{B}$ cells induces monocyte recruitment and infiltration, further enhancing the inflammatory response and cardiac tissue damage. Accordingly, B cell depletion disrupts the inflammatory response, reducing the levels of both local and systemic pro-inflammatory cytokines. Moreover, B cell population numbers may be regulated via Baff receptors (Baff-r), CD20 antibodies, and Baff antibodies. Depletion of $\mathrm{B}$ cells via the aforementioned mechanisms enables several pathways whereby CCL7 production may be depleted, which ultimately rescues cardiac function through reduction of cardiac injury. Depletion of mature B cells has also been demonstrated to improve post-ischemic ventricular remodelling, thus improving cardiac function [45]. Overall, there exists a molecular network under which several immune cell types, including $\mathrm{T}$ and $\mathrm{B}$ cells, mediate both IHD injury and healing processes.

\section{Discussion}

This systematic review aims to characterize the mechanisms by which the relevant immune cell typesmacrophages, monocytes, platelets, endothelial cells, CD4+ $\mathrm{T}$ cells, and B cells - participate in IHD pathogenesis and injury. In sum, the aforementioned cell types function in the induction and sustaining of inflammation whereby monocytes and macrophages interact with chemokine receptors and cytokines [30]; activated platelets aggregate at the rupture site and activate gene endothelial cell gene expression programs $[32,33,36]$; and CD4+ T cells and B cells participate in IFN-y and CCL7 signaling [42-45]. Considering the above, we will discuss potential therapeutic targets and research directions for the development of improved IHD treatments.

In the event of atherosclerotic plaque build-up, the interaction of chemokines with specific chemokine receptors and adhesion molecules on endothelial cells help to recruit monocytes. In tissues, these monocytes differentiate into macrophages, and both cell types sustain inflammation. A potential therapeutic intervention may involve disrupting the chemokine/chemokine-receptor interaction, potentially through the expression of noncompetitive inhibitor molecules. Furthermore, studies have shown that the deletion of Scavenger Receptor A reduces plaque macrophage proliferation [33], providing an additional avenue to limit inflammation through manipulating gene expression. However, because of the non-specific nature of the innate immune response-which protects patients from general infections, not just ischemic injury - targeting inflammation might be problematic. Another potential therapeutic avenue is MIF inhibitory therapy, whereby MIF deficiency could serve a protective function against ischemia/reperfusion (I/R) injury through the suppression of a variety of inflammatory responses. Mice studies have demonstrated that the duration of ischemia and reperfusion determines the severity of local inflammation and damage, and that MIF knockout mice show significantly attenuated infarct sizes, indicating the vital role of MIF in I/R injury [25].

Considering the vital role of elevated endothelial cell gene expression in the repair of ruptured vessels, a promising therapeutic approach may be upregulating VEGF expression [36]. However, as this finding was elucidated in rat models, doubts remain about the translational potential to human biology. Furthermore, endothelial cells secrete miRNA-containing exosomes; these pro-angiogenic microRNAs induce angiogenesis - the process by which blood vessels are formed. As such, exosomal miRNAs reconstitute vasculature through the restoration of blood vessels and may serve as a potential therapeutic 
UNDERGRADUATE RESEARCH IN NATURAL AND CLINICAL SCIENCE AND TECHNOLOGY (URNCST) JOURNAL Read more URNCST Journal articles and submit your own today at: $\underline{\text { https://www.urncst.com }}$

intervention for IHD-induced vessel damage [46]. This microRNA-mediated angiogenesis may be further stimulated through treatment with promoting factors such as fibroblast growth factor (FGF) or VEGF cytokines [47]. Past drug trials with coronary disease patients also put forth antiplatelet drug treatment as a promising intervention against platelet-induced inflammation [33].

Regarding lymphocyte involvement, CD4+ T cells interact with the IFN-y expression pathway to induce inflammation and injury [42-44]. Accordingly, potential therapeutic approaches include targeting IFN-y signaling molecules as well as their agonists and inhibitors. Prior to such studies, it is crucial to improve the characterization of the mechanisms by which CD4+ T cells act within the IFN$\mathrm{\gamma}$ pathway. Relatedly, CD4+-dependent injury may be mitigated by A2A receptor signaling [42]. Thus, A2A agonists serve as an attractive candidate drug molecule for IHD treatment. It is important to acknowledge, however, that the mitigating effects of A2A agonists were demonstrated in RAG1 KO mice, which may not necessarily recapitulate physiological conditions within mice, thus further complicating extrapolation to clinical trials with human patients [42-44]. Finally, considering the role of B cells in inflammation via CCL7 production, potential experiments inhibiting CCL7 production through regulating Baff receptors, CD20 antibodies, and Baff antibodies may provide insight into the mechanisms of cardiac injury [45]. Again, discretion must be exercised as disruption of CCL7 production may yield unfavorable offtarget results outside of the cardiac system.

Immune cells and their function interact with one another. Cardiac macrophages have been shown to be in contact with endothelial cells and monocytes, suggesting that these macrophages are associated with endocrine signalling within the vasculature [20]. Accordingly, through combined function, these immune cell types may play a role in cardiomyocyte homeostasis and potential immunomodulatory functions within the heart. Additionally, cardiac macrophages express a complementary binding protein which suppresses T-cell activation, demonstrating how various immune cell types may cross-regulate one another. On the other hand, cardiac macrophages also enhance the growth and remodelling of cardiomyocytes. [48]. Furthermore, macrophages release interleukin-18 (IL-18), which promotes cardiomyocyte growth and exacerbates cardiac dysfunction. Along with monocytes, macrophages prolong inflammation, causing instability of the endothelial layer with which macrophages and monocytes are closely in contact [16].

Destabilization of the vascular wall activates the platelet system, which initiates tissue restoration. [16]. As a result, the endothelial cells surface proteins to be activated, leading to the activation of platelets, neutrophils, and other plasma proteins. Specifically, the surface proteins Pselectins and ICAM-1 allow the binding of macrophages and monocytes [40]. Platelet granules release

Liu et al. | URNCST Journal (2021): Volume 5, Issue 10 DOI Link: https://doi.org/10.26685/urncst.311 proinflammatory proteins, which prompt the surface expression of ICAM-1 [40]. It is evidenced that surface proteins, such as P-selectins and ICAM-1, activate platelets and leukocytes, exacerbating the injury from the ischemic event. Cytokines play a key role in inflammation [8]. CD4+ helper $\mathrm{T}$ cells induce inflammation using cytokines. Specifically, T-helper cell 1 (Th1), causes the production of cytokines such as IFN- $\gamma$, thus promoting inflammation at the site. IFN- $\gamma$ aids macrophages in eradicating infected cells and helps B-cells procure antibodies. Additionally, macrophage MIF controls the release of cytokines, exacerbating inflammation at the site [28]. MIF is also a cytokine itself, and thus plays a significant role in facilitating inflammation. Specifically, the toll-like receptor-4 (TLR-4) pathway is employed in the innate immune response. As well, the TLR4 pathway serves to regulate the "set point" of inflammation in response to certain triggers by controlling cell activation. Importantly, its pathological role has been reported in several other disorders involving inflammation, like rheumatoid arthritis.

\section{Conclusions}

Ultimately, mice studies provide a useful baseline for transition into clinical trials and the testing of candidate drug molecules. Still, it is important to acknowledge the shortcomings of a mouse model system, which lack the intricacies and accuracy of human clinical trials. As such, further testing with more closely related animal models and primates will offer better insights into IHD pathogenesis and injury. Prospective longitudinal studies with IHD patients will also strengthen previously established frameworks and complete the present understanding of IHD pathology. At heart, it is evident that a diverse group of cell types act in the pathogenesis and injury of IHD, demonstrating a complex interconnected landscape of molecular interactions.

\section{List of Abbreviations Used}

$\mathrm{A} 2 \mathrm{~A}$ : adenosine $\mathrm{A} 2 \mathrm{~A}$ receptor

Baff-r: baff receptors

CAD: coronary artery disease

CAM: cell adhesion molecule

CCL7: chemokine C-C motif ligand 7

FGF: fibroblast growth factor

KO: knockout

IC: ischemic cardiomyopathy

ICAM-1: endothelial cell intracellular adhesion molecule 1

IFN-y: interferon gamma

IHD: ischemic heart disease

IL-18: interleukin-18

I/R: ischemia/reperfusion

MI: myocardial infarction

MIF: migration inhibitory factor

miRNA: micro-RNA

MPV: mean platelet volume

PDW: platelet distribution width 
UNDERGRADUATE RESEARCH IN NATURAL AND CLINICAL SCIENCE AND TECHNOLOGY (URNCST) JOURNAL Read more URNCST Journal articles and submit your own today at: https://www.urncst.com

P-LCR: platelet large cell ratio

TLR-4: toll-like receptor 4

VEGF: vascular endothelial growth factor

\section{Conflicts of Interest}

The authors declare that they have no conflicts of interest.

\section{Ethics Approval and/or Participant Consent}

This study did not require ethics approval and/or participant consent as it is a systematic review.

\section{Authors' Contributions}

JL: contributed to the conception and analysis of the review, drafted and revised the content, and gave final approval of the version to be published.

VM: contributed to the conception and analysis of the review, drafted and revised the content, and gave final approval of the version to be published.

IT: contributed to the conception and analysis of the review, drafted and revised the content, and gave final approval of the version to be published.

\section{Acknowledgements}

We would like to thank our mentor Joseph Lee for his advice and encouragement.

\section{Funding}

This study was not funded.

\section{References}

[1] Khan MA, Hashim MJ, Mustafa H, Baniyas MY, Al Suwaidi SK, AlKatheeri R, Alblooshi FM, Almatrooshi ME, Alzaabi ME, Al Darmaki RS, Lootah SN. Global epidemiology of ischemic heart disease: Results from the global burden of disease study. Cureus. 2020 Jul;12(7). https://doi.org/10.7759/cureus.9349

[2] Institute of Medicine (US) Committee on Social Security Cardiovascular Disability Criteria. Cardiovascular Disability. National Academies Press; 2010.

[3] Eltzschig HK, Eckle T. Ischemia and reperfusion - From mechanism to translation. Nature Medicine. 2011;17(11):1391-401. https://doi.org/10.1038/nm.2507

[4] Valeur HS, Valen G. Innate immunity and myocardial adaptation to ischemia. Basic research in cardiology. 2009;104(1):22-32. https://doi.org/10.1007/s00395008-0756-6

[5] Pluijmert NJ, Atsma DE, Quax PHA. Post-ischemic myocardial inflammatory response: A complex and dynamic process susceptible to immunomodulatory therapies. Frontiers in Cardiovascular Medicine. 2021;8:647785-647785. https://doi.org/10.3389/fcvm $\underline{.2021 .647785}$

Liu et al. | URNCST Journal (2021): Volume 5, Issue 10 DOI Link: https://doi.org/10.26685/urnest.311
[6] Jensen, R. V., Hjortbak, M. V., \& Bøtker, H. E. Ischemic heart disease: An update. In Seminars in Nuclear Medicine. 2020 May;50(3):195-207. http://doi.org/10.1053/j.semnuclmed.2020.02.007

[7] Prasad D., Kabir Z, Revathi Devi K, Peter PS, Das B. Prevalence and risk factors for silent myocardial ischemia (PRISM): A clinico observational study in patients of type 2 diabetes. Indian Heart Journal. 2019;71(5):400-5. https://doi.org/10.1016/j.ihj.2019 .12 .002

[8] Boag, S. E., Andreano, E., \& Spyridopoulos, I. Lymphocyte communication in myocardial ischemia/reperfusion injury. Antioxidants \& Redox Signaling. 2017;26(12):660-675. https://doi.org/ 10.1089/ars.2016.6940

[9] Rusinkevich V, Huang Y, Chen Z-Y, Qiang W, Wang Y-G, Shi Y-F, et al. Temporal dynamics of immune response following prolonged myocardial ischemia/reperfusion with and without cyclosporine A. Acta Pharmacologica Sinica. 2019;40(9):1168-83. https://doi.org/10.1038/s4140411-018-0197-1

[10]Zuidema, M. Y., \& Zhang, C. Ischemia/reperfusion injury: The role of immune cells. World Journal of Cardiology. 2010;2(10):325-332. https://doi.org/ 10.4330/wjc.v2.i10.325

[11] Strassheim D, Dempsey EC, Gerasimovskaya E, Stenmark K, Karoor V. Role of inflammatory cell subtypes in heart failure. Journal of Immunology Research. 2019;2019:2164017-9. https://doi.org/ 10.1155/2019/2164017/

[12] Murphy K, Weaver C. Janeway's immunobiology. Garland Science; 2016 Mar 1.

[13] Kaplan ZS, Jackson SP. The role of platelets in atherothrombosis. Hematology 2010, The American Society of Hematology Education Program Book. 2011 Dec 10;2011(1):51-61. https://doi.org/10.1016/ j.amjcard.2008.11.017

[14] Mai J, Virtue A, Shen J, Wang H, Yang XF. An evolving new paradigm: Endothelial cells-conditional innate immune cells. Journal of Hematology \& Oncology. 2013 Dec;6(1):1-3. https://doi.org/10.1186/ 1756-8722-6-61

[15] Ramji DP, Davies TS. Cytokines in atherosclerosis: Key players in all stages of disease and promising therapeutic targets. Cytokine \& Growth Factor Reviews. 2015 Dec 1;26(6):673-85. https://doi.org/ 10.1016/j.cytogfr.2015.04.003

[16] Nahrendorf M, Swirski FK. Innate immune cells in ischaemic heart disease: Does myocardial infarction beget myocardial infarction? European Heart Journal. 2016;37(11):868-72. https://doi.org/10.1093/eurheartj/ $\underline{\text { ehv453 }}$ 
UNDERGRADUATE RESEARCH IN NATURAL AND CLINICAL SCIENCE AND TECHNOLOGY (URNCST) JOURNAL Read more URNCST Journal articles and submit your own today at: https://www.urncst.com

[17] Varbo A, Benn M, Tybjærg-Hansen A, Nordestgaard BG. Elevated remnant cholesterol causes both low-grade inflammation and ischemic heart disease, whereas elevated low-density lipoprotein cholesterol causes ischemic heart disease without inflammation. Circulation. 2013;128(12):1298-309. https://doi.org/ 10.1161/CIRCULATIONAHA.113.003008

[18] Lowe GD., Yarnell JW., Rumley A, Bainton D, Sweetnam PM. C-reactive protein, fibrin D-dimer, and incident ischemic heart disease in the speedwell study: Are inflammation and fibrin turnover linked in pathogenesis? Arteriosclerosis, Thrombosis, and Vascular Biology. 2001;21(4):603-10. https://doi.org/ 10.1161/01.atv.21.4.603

[19] Mann D., McMurray JJ., Packer M, Swedberg K, Borer J., Colucci W., et al. Targeted anticytokine therapy in patients with chronic heart failure - Results of the randomized etanercept worldwide evaluation (renewal). Circulation. 2004;109(13):1594-602. https://doi.org/10.1161/01.CIR.0000124490.27666.B2

[20] Pinto AR, Paolicelli R, Salimova E, Gospocic J, Slonimsky E, Bilbao-Cortes D, et al. An abundant tissue macrophage population in the adult murine heart with a distinct alternatively-activated macrophage profile. PloS ONE. 2012;7(5):e36814-e36814. https://doi.org/10.1371/journal.pone.0036814

[21] Heidt T, Courties G, Dutta P, Sager HB, Sebas M, Iwamoto Y, et al. Differential contribution of monocytes to heart macrophages in steady-state and after myocardial infarction. Circulation Research. 2014; 115(2):284-95. https://doi.org/10.1161/CIRCRESAHA .115 .303567

[22] Epelman S, Lavine KJ, Beaudin AE, Sojka DK, Carrero JA, Calderon B, et al. Embryonic and adultderived resident cardiac macrophages are maintained through distinct mechanisms at steady state and during inflammation. Immunity. 2014;40(1):91-104.

https://doi.org/10.1016/j.immuni .2013 .11 .019

[23] Ley K, Miller YI, Hedrick CC. Monocyte and macrophage dynamics during atherogenesis. Arteriosclerosis, Thrombosis, and Vascular Biology. 2011;31(7):1506-16. https://doi.org/10.1161/ATVBAHA .110 .221127

[24] Moore KJ, Tabas I. Macrophages in the pathogenesis of atherosclerosis. Cell. 2011;145(3):341-55. https://doi.org/10.1016/j.cell.2011.04.005

[25] Swirski FK, Nahrendorf M. Leukocyte behavior in atherosclerosis, myocardial infarction, and heart failure. Science (American Association for the Advancement of Science). 2013;339(6116):161-6. https://doi.org/10.1126/science.1230719

[26] Frantz S, Nahrendorf M. Cardiac macrophages and their role in ischaemic heart disease. Cardiovascular Research. 2014;102(2):240-8. https://doi.org/10.1093/ cvr/cvu025

Liu et al. | URNCST Journal (2021): Volume 5, Issue 10 DOI Link: https://doi.org/10.26685/urncst.311
[27] van der Laan AM, ter Horst EN, Delewi R, Begieneman MPV, Krijnen PAJ, Hirsch A, et al. Monocyte subset accumulation in the human heart following acute myocardial infarction and the role of the spleen as monocyte reservoir. European Heart Journal. 2014;35(6):376-85. https://doi.org/10.1093/ eurheartj/eht331

[28] Gao X-M, Liu Y, White D, Su Y, Drew BG, Bruce CR, et al. Deletion of macrophage migration inhibitory factor protects the heart from severe ischemiareperfusion injury: A predominant role of antiinflammation. Journal of Molecular and Cellular Cardiology. 2011;50(6):991-9. https://doi.org/10.1016/ j.yjmcc.2010.12.022

[29] Hilgendorf I, Gerhardt LM., Tan TC, Winter C, Holderried TA., Chousterman BG, et al. Ly-6Chigh monocytes depend on Nr4a1 to balance both inflammatory and reparative phases in the infarcted myocardium. Circulation Research. 2014;114(10):161122. https://doi.org/10.1161/CIRCRESAHA.114.303204

[30] Nahrendorf M, Swirski FK. Monocyte and macrophage heterogeneity in the heart. Circulation Research. 2013;112(12):1624-33. https://doi.org/10.1161/ CIRCRESAHA.113.300890

[31] Frangogiannis NG. The inflammatory response in myocardial injury, repair, and remodelling. Nature Reviews Cardiology. 2014;11(5):255-65. https://doi.org/ $\underline{10.1038 / \text { nrcardio. } 2014.28}$

[32] Khandekar MM, Khurana AS, Deshmukh SD, Kakrani AL, Katdare AD, Inamdar AK. Platelet volume indices in patients with coronary artery disease and acute myocardial infarction: An Indian scenario. Journal of Clinical Pathology. 2006 Feb 1;59(2):146-9. https://doi.org/10.1136/jcp.2004.025387

[33] Frossard M, Fuchs I, Leitner J, Hsieh K, Vlcek M, Losert $\mathrm{H}$ et al. Platelet function predicts myocardial damage in patients with acute myocardial infarction. Circulation. 2004;110(11):1392-1397. https://doi.org/ 10.1161/01.CIR.0000141575.92958.9C

[34] Lee SH, Du J, Stitham J, Atteya G, Lee S, Xiang Y, Wang D, Jin Y, Leslie KL, Spollett G, Srivastava A, Mannam P, Ostriker A, Martin KA, Tang WH, Hwa J. Inducing mitophagy in diabetic platelets protects against severe oxidative stress. EMBO Molecular Medicine. 2016;8:779-795. https://doi.org/10.15252/ emmm.201506046

[35] Murry CE, Jennings RB, Reimer KA. Preconditioning with ischemia: A delay of lethal cell injury in ischemic myocardium. Circulation. 1986;74:1124-1136. https://doi.org/10.1161/01.CIR.74.5.1124

[36] Gidlof O, Brug M, Ohman J, Gilje P, Olde B, Wahlestedt $\mathrm{C}$ et al. Platelets activated during myocardial infarction release functional miRNA which can be taken up by endothelial cells and regulate ICAM1 expression. The FASEB Journal. 2013;27(S1). https://doi.org/10.3389/fphys.2021.658524 
UNDERGRADUATE RESEARCH IN NATURAL AND CLINICAL SCIENCE AND TECHNOLOGY (URNCST) JOURNAL

Read more URNCST Journal articles and submit your own today at: https://www.urncst.com

[37] Albrecht-Schgoer K, Schgoer W, Holfeld J, Theurl M, Wiedemann D, Steger $\mathrm{C}$ et al. The angiogenic factor secretoneurin induces coronary angiogenesis in a model of myocardial infarction by stimulation of vascular endothelial growth factor signaling in endothelial cells. Circulation. 2012;126(21):24912501. https://doi.org/10.1161/CIRCULATIONAHA .111 .076950

[38] Chen G, Yang Y, Tang R, Huang C. Activation of MIR-145/P70S6K1/ENOS pathway in microvascular endothelial cells by tongxinluo alleviates myocardial ischemia/reperfusion injury-role of exosomal LINCROR from cardiomyocytes. Journal of the American College of Cardiology. 2019;73(9):46-46. https://doi.org/10.1016/S0735-1097(19)30655-2

[39] Fioret BA, Heimfeld JD, Paik DT, Hatzopoulos AK. Endothelial cells contribute to generation of adult ventricular myocytes during cardiac homeostasis. Cell Reports. 2014;8(1):229-41. https://doi.org/ 10.1016/j.celrep.2014.06.004

[40] Singhal AK, Symons JD, Boudina S, Jaishy B, Shiu YT. Role of endothelial cells in myocardial ischemiareperfusion injury. Vascular Disease Prevention. 2010;7:1. https://doi.org/10.2174/187412070100701 $\underline{0001}$

[41] Hofmann, U., \& Frantz, S. Role of T cells in myocardial infarction. European Heart Journal. 2016;37(11):873-879. https://doi.org/10.1093/eurheartj/ehv639

[42] Yang, Z., Day, Y. J., Toufektsian, M. C., Xu, Y., Ramos, S. I., Marshall, M. A., \& Linden, J. Myocardial infarct-sparing effect of adenosine A2A receptor activation is due to its action on CD4+ T lymphocytes. Circulation. 2006;114(19):2056-2064. https://doi.org/ $\underline{10.1161 / C I R C U L A T I O N A H A .106 .649244}$
[43] Boag, S. E., Andreano, E., \& Spyridopoulos, I. Lymphocyte communication in myocardial ischemia/reperfusion injury. Antioxidants \& Redox Signaling. 2017;26(12):660-675. https://doi.org/ 10.1089/ars.2016.6940

[44] Boag, S. E., Das, R., Shmeleva, E. V., Bagnall, A., Egred, M., Howard, N., \& Spyridopoulos, I. T lymphocytes and fractalkine contribute to myocardial ischemia/reperfusion injury in patients. The Journal of Clinical Investigation. 2015;125(8):3063-3076. https://doi.org/10.1172/JCI80055

[45]Zouggari, Y., Ait-Oufella, H., Bonnin, P., Simon, T., Sage, A. P., Guérin, C., \& Mallat, Z. B lymphocytes trigger monocyte mobilization and impair heart function after acute myocardial infarction. Nature Medicine. 2013;19(10):1273-1280. https://doi.org/ 10.1038/nm.3284

[46] Moghiman T, Barghchi B, Esmaeili S-A, Shabestari MM, Tabaee SS, Momtazi-Borojeni AA. Therapeutic angiogenesis with exosomal microRNAs: An effectual approach for the treatment of myocardial ischemia. Heart Failure Reviews. 2021;26(1):205-13. https://doi.org/10.1007/s10741-020-10001-9

[47]Mitsos S, Katsanos K, Koletsis E, Kagadis GC, Anastasiou N, Diamantopoulos A, Karnabatidis D, Dougenis D. Therapeutic angiogenesis for myocardial ischemia revisited: Basic biological concepts and focus on latest clinical trials. Angiogenesis. 2012;15(1):1-22. https://doi.org/10.1007/s10456-011-9240-2

[48] Gomez I, Duval V, Silvestre J. Cardiomyocytes and macrophages discourse on the method to govern cardiac repair. Frontiers in Cardiovascular Medicine. 2018;5(134). https://doi.org/10.3389/fcvm.2018.00134

\section{Article Information}

Managing Editor: Jeremy Y. Ng

Peer Reviewers: Joseph Lee, Foram Vyas

Article Dates: Received Aug 07 21; Accepted Oct 12 21; Published Oct 2921

\section{Citation}

Please cite this article as follows:

Liu JJ, Moosa VA, Tan IJ. The role of immune cell types in ischemic heart disease progression: A systematic review.

URNCST Journal. 2021 Oct 29: 5(10). https://urncst.com/index.php/urncst/article/view/311

DOI Link: https://doi.org/10.26685/urncst.311

\section{Copyright}

(C) Jenny J. Liu, Vaneeza A. Moosa, Isabelle J. Tan. (2021). Published first in the Undergraduate Research in Natural and Clinical Science and Technology (URNCST) Journal. This is an open access article distributed under the terms of the Creative Commons Attribution License (https://creativecommons.org/licenses/by/4.0/), which permits unrestricted use, distribution, and reproduction in any medium, provided the original work, first published in the Undergraduate Research in Natural and Clinical Science and Technology (URNCST) Journal, is properly cited. The complete bibliographic information, a link to the original publication on http://www.urncst.com, as well as this copyright and license information must be included. 


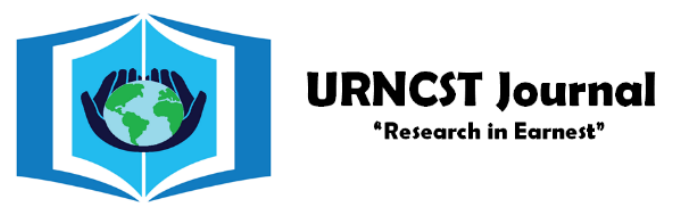

\section{Funded by the Government of Canada}

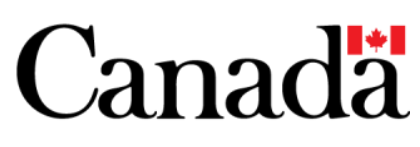

Do you research in earnest? Submit your next undergraduate research article to the URNCST Journal!

| Open Access | Peer-Reviewed | Rapid Turnaround Time | International | | Broad and Multidisciplinary | Indexed | Innovative | Social Media Promoted |

Pre-submission inquiries? Send us an email at info@ urncst.com | Facebook, Twitter and LinkedIn: @URNCST Submit YOUR manuscript today at https://www.urncst.com! 